\title{
Non-linearity in timing the equity market and debt-equity choice of UK firms.
}

\author{
HafezaliIqbalHussain*1 ${ }^{1}$, Noor Hafidzah Jabarullah ${ }^{2}$ \\ ${ }^{1}$ Hull University Business School, University of Hull, Hull, HU6 7RX,UK \\ ${ }^{2}$ Department of Physics and Mathematics, University of Hull, Hull, HU6 7RX,UK
}

\begin{abstract}
We empirically test the market timing theory of capital structure of issuing behavior of UK firms and find that the debt-equity choice decision is non-linear. In line with the previous literature, we find that managers are more likely to issue equity (debt) when equities are overvalued (undervalued). In further analyzing the issuing pattern, we find that managers' inclination towards equity issues during periods of overvaluation is nonlinear as it is only significant during periods of slight overvaluation and insignificant during periods of excessive overvaluation. On the other hand, probabilities of issuing debt significantly increase only when equities are excessively undervalued. Our findings suggest that managers' take into account other considerations when timing the equity market and poses some interesting questions on the viability of market timing as a stand-alone theory in explaining the capital structure puzzle.
\end{abstract}

Keywords: Capital structure, equity mispricing, market timing, UK firms.

\section{Introduction}

This paper looks at the effect of equity mispricing on the debt-equity choice. We empirically test the market timing theory of capital structure. Based on the theoretical predictions, managers' would increase debt (equity) issues during periods of overvaluation (undervaluation). The assumption of our study is that managers are able to identify periods of equity mispricing and thus exploit such windows of opportunities to change the financing mix to lower overall cost of capital.

The literature shows that there have been mixed results on the ability of market timing theory to predict firms' security issue choices. Several studies find evidence that favors the market timing theory (e.g. Baker and Wurgler[1] andHovakimian et al. [2]) while others have contended their findings (e.g.Hovakimian[3] and Mahajan and Tartaroglu[4]). In light of this we provide evidence of earnings based test on the ability of market timing theory to explain security issue choice. Our study looks at UK firms in order to confirm the ability of the theory in a different market. Furthermore, we look at how managers react to different levels of mispricing in order to capture managerial issuing behavior. To the best of our knowledge, we are the first to show that managers' reaction to different levels of undervaluation and overvaluation is non-linear, contrary to expectations indicating that several different factors come into play besides equity mispricing when managers make an issue choice.

In order to capture the managerial behavior at different levels of mispricing, we split our sample into undervalued and overvalued firm year observations. We find that firms' are only likely to prefer debt issues versus equity issues during periods of moderate of high undervaluation. It could be that managers might be avoiding the commitment of interest payments in the future that comes with increasing debt issues and are only more likely to issue debt as equity prices are extremely deflated. Furthermore, their actions could also be triggered by the intention of sending out a signal to the market indicating that equities are undervalued. These points towards a pecking-order of security preference which is market oriented where managers only resort to debt financing if cost of equity is too high (when equity prices are too low). When looking at periods of overvaluation, we find that managers are more likely to issue equity during periods of overvaluation only when the extent of overvaluation is low or moderate. They are unlikely to issue equity when the extent of overvaluation is high. It could be that managers do not see prices being sustained at extremely high levels if they announce an equity issue due to the signaling effect.

Our paper is structured as follows. We discuss the relevant literature in the next section while section three looks at data, variable definitions, describes the residual income model used to measure equity mispricing and look at the models used in the analysis. Section four looks at the empirical results and section five concludes the paper.

\section{Literature Review}

This section reviews the relevant literature on the effect of equity mispricing on the debt-equity of UK firms. In a recent paper, Baker and Wurgler [1] proposed an alternative explanation of capital structure. The authors argue that the current capital structure of a given firm is the outcome of previous attempts by managers' 
to time the equity market. In their study, they argue that the empirical results favour an approach where rational managers are able to identify windows of opportunity due to investor irrationality, to time the equity market and thus lowering the cost of capital, in turn increasing firm value. Their empirical evidence supports the market timing theory of capital structure.

\subsection{Debt Equity-Choice And Equity Prices}

Baker and Wurgler [1] empirically test the change in leverage ratios of US firms and find a significant relationship between the external finance weighted average market-to-book ratio which indicates that firms adjust security issues based on levels of external valuations. This would mean that managers are actively engage in market timing and thus time the equity market based on the level of equity mispricing. Thus, they conclude that capital structure is the cumulative outcome of managers' timing attempts. Further evidence on the timing motive is evidenced in the survey by Graham and Harvey [5] where managers are issuing equity when prices are rising. In line with the scope of our study, evidence for UK firms' issuing behavior influenced by timing motivations is provided by in the literature as well[6]. In their study, managers indicate that two of the four most significant factors affecting debt levels in the UK are based on equity market mispricing and timing motives. ${ }^{1}$ Marsh [7] also finds evidence to support the market timing explanation of capital structure where UK firms tend to issue equity when prices are high.

Contradictory to the studies above, Flannery and Rangan[8] find evidence that supports the trade-off theory rather than the market timing theory. The authors find that more than half of the observed changes in leverage levels can be explained by firms adjusting to target levels whilst less than a tenth of changes are brought about by motives to time the market and finance a deficit. Hovakimian [3] provides further contention by showing that the negative correlation documented between the market-to-book ratio and leverage levels are brought about by growth considerations rather than timing the equity market. In another empirical study, Mahajan and Tartaroglu [4] find that the negative correlation between leverage and market-to-book supports the dynamic trade-off explanation rather than the market timing view. Thus the on-going debate in the literature provides room for contribution in examining the market timing theory.

\subsection{Non-Linearity In The Debt-Equity Choice}

Based on the differing findings in the literature as discussed above, we propose an argument of nonlinear behavior in the debt-equity choice. Byoun [9] provides some insight on the non-linear issuing behavior as the author finds that firms adjust to target levels faster when they are above relative to when they are under target levels. Furthermore, firms' speed of adjustment is also influenced by whether they are in a deficit versus when they are having surpluses. Firms tend to adjust faster when they are under (over) levered faced with a financing deficit (surplus). In another study, Warr et al.[10] show that equity mispricing also influences speed of adjustment, suggesting non-linear behavior in issuing choices. Their study shows that firms adjust faster to target levels when they are under-levered and when equities are undervalued (relative to when they are overvalued). Furthermore, speed of adjustment is also faster when firms are over-levered and when equities are overvalued (relative to when equities are undervalued). The implications would point towards a higher likelihood of timing the equity market in a non-linear fashion and when they are timing issues strategically (considering the cost of not-issuing or not-repurchasing securities). Given the findings in the literature, we conjecture that the debt-equity choice can be explained by a non-linear function that is based on the extent of equity mispricing.

\subsection{Data Description And Descriptive Statistics}

\section{Data And Method}

Our sample starts from all UK firms available in the Datastream Thomson Reuters database. The selected period for our study is $1992-2011$. We exclude data from the pre-1992 period as data is scarcely available. The data selection is based on data availability, where firm-year observations with missing data are dropped and the objective of measuring equity mispricing in order to capture the timing effect on the debt-equity choice. To avoid the pitfall of selection and survivorship bias, we include dead firms in our sample. Drawing from the literature on UK studies of capital structure, we exclude financial firms. The use of unbalanced panel data in our study allows for better inference of model parameters, more accurate capturing of firms' issuing behavior due to econometric efficiency and limiting the impact of omitted variables which allow the control of missing or unobservable variables. The variables used in the study are defined as follows. Net debt issues, is the net change in

\footnotetext{
${ }^{1}$ The authors record that the top four factors affecting leverage levels are issuing debt when interest levels are low, financing a deficit, equity undervaluation and changes in price of common stock.
} 
book debt over total assets. Net equity issues, is the change in book equity less the change in retained earnings divided by total assets. SIZE is defined as the natural logarithm of total assets to millions of 1992 pounds. Non debt tax shield, NDTS, is the ratio of depreciation to total assets. Asset tangibility (TANG) is net plant, property and equipment over total assets. Industry leverage, (IL) is the median of the leverage levels of the industry the firm operates in. Effective tax rate (TR) is total tax to total taxable income. We proxy for growth option using research and development expenses (RDE) and capital expenditure (CEX), which are defined as research and development expenses scaled by total assets, and capital expenditure divided by total assets. Furthermore, we introduce a dummy variable, RDED, which takes the value of 1 if the data item is not available in Datastream and zero otherwise.

To control for outliers, we remove firm year observations when total leverage, net debt issued and net equity issued exceeds $100 \%$. The final sample comprises of 3108 firm-year observations. We summarize the firm specific characteristics and financing patterns of the sample in Table 1. The table presents mean figures whilst standard deviations are reported in parentheses. Firms that issue debt have equities that are undervalued $72 \%$ of the time while firms that issue equity on the other hand have equities which are overvalued $80 \%$ of the time. Thus we are able to infer that equity mispricing plays a significant role in financing from the summary statistics.

\begin{tabular}{|c|c|c|}
\hline & Debt Issuers & Equity Issuers \\
\hline Net Debt Issued & $0.1314(0.0734)$ & $0.0023(0.0251)$ \\
\hline Net Equity Issued & $0.0005(0.0790)$ & $0.2887(0.2561)$ \\
\hline Non-Debt Tax Shield (NDTS) & $0.0364(0.0474)$ & $0.0280(0.0402)$ \\
\hline Size (SIZE) & $10.967(1.9112)$ & $9.5120(1.8968)$ \\
\hline Tangibility (TAN) & $0.3920(0.2670)$ & $0.2936(0.2420)$ \\
\hline Effective Tax Rate (TR) & $0.2420(1.3110)$ & $0.1721(1.1096)$ \\
\hline Leverage (LEV) & $0.2894(0.1422)$ & $0.0912(0.1387)$ \\
\hline Capital Expenditure (CEX) & $0.0864(0.0841)$ & $0.0554(0.0712)$ \\
\hline Research and Development Expenses (RDE) & $0.0076(0.0314)$ & $0.0391(0.0994)$ \\
\hline$\%$ IVMV $>1$ & $72 \%$ & $20 \%$ \\
\hline $\mathrm{N}$ (observations) & 1312 & 1120 \\
\hline
\end{tabular}

Note: Figures reported are mean values while standard deviations are reported in parentheses.

\subsection{Equity Mispricing And Empirical Model}

We measure equity valuation using the residual income which is used in similar studies in the literature [11], [12]. Equity mispricing is defined as the ratio of intrinsic value (IV) to the current market value (MV) (see D'Mello and Shroff[13] for a more detailed review of this method). Our approach is based on the study by Rhodes-Kropf et al.[14] who decompose the market-to-book ratio into two separate components: to measure growth options and to measure valuation. In their paper, the authors argue that value-to-market measures mispricing while book-to-value measures growth opportunities.

Thus intrinsic value is calculated based on Elliott et al.[11] and Elliott et al.[12] where intrinsic value is:

$$
I V_{0}=B E_{0}+\sum_{t=1}^{T}(1+k)^{-t} E E_{0}\left[I_{t}-k\right] \times B E_{t-1}+\frac{(1+k)^{-T}}{k} T V
$$

Terminal value, $\mathrm{TV}$, is calculated as follows:

$$
T V=E E_{i 0}\left[\left(I_{T}-k \times B E_{T-1}\right)+\left(I_{T+1}-k \times B E_{T}\right)\right] / 2
$$

where $I V_{0}$ is the intrinsic value of the firm's equity at time $0, B E_{0}$ is the book value of equity at time 0 , $k$ is the cost of equity, and $E E_{0}\left(I_{i}\right)$ is the expected earnings for period $\mathrm{t}$ at time 0 . Time 0 is defined as the previous fiscal year and $\mathrm{T}$ is set to equal 2 years. We utilize a similar approach to Elliott et al. [11] and Elliott et al.[12] who use 3 years of future growth earnings. In their study, the authors state that although this approach may appear to be too short a time period to capture all future growth opportunities of the firm, residual income model does not capitalize raw earnings but employs abnormal earnings (as in Economic Value Added approach). Drawing further from their study we use a perfect foresight version of residual income model[13]. Thus we define BE as book value of equity and $\mathrm{I}_{\mathrm{i}}$ as income before extraordinary items.

The authors argue that although this might appear to be too short a time period to capture all future growth opportunities of the firm, the residual income model does not capitalize raw earnings but employs abnormal earnings (as in Economic Value Added). Similar to their study, we use a perfect foresight version of 
residual income model[13]. Therefore, we define $\mathrm{BE}$ as book value of equity and $\mathrm{I}_{\mathrm{i}}$ as income before extraordinary items.

In addition, we further utilize their approach and use ex-post realization of earnings which maximizes the sample size. However, this approach suffers from several issues, notably the issue of endogeneity. The authors argue that this issue leads to a bias against our study finding evidence of equity mispricing influencing issuing behavior, given that debt issues further reduces future earnings due to commitments from interest payments. Our study uses the Fama and French [15] three factor model to estimate the industry cost of equity, $k$. The results are however robust to using a simple one factor model to estimate the cost of equity capital. Short term treasury bills are used to proxy for the risk free rate. Terminal value is calculated as the average value of the last 2 years of the finite time series and is restricted to positive values as including negative values would indicate that managers would continuously invest in negative NPV projects. Similar to Elliott et al. [11] and Elliott et al. [12] our study uses future realized earnings and assumes a perfect and unbiased foresight by managers, thus we are able to proxy for managers more informed expectations of future earnings. The authors point out that their approach is justifiable given the purpose of measuring equity mispricing is to measure the extent of deviation from fundamental of equities and not to create a trading based rule.

Our main aim is the measure the deviation of market prices of equities from intrinsic value; we include a ratio of intrinsic value to market value (IVMV) in our regressions. Our basic model is as follows: ${ }^{2}$

$$
\text { Issue Type }_{i t}=B_{0} \text { Constant }+B_{1} I V M V+\gamma[\text { Control Variables }]_{i t}+\varepsilon_{i t}
$$

where Issue Type ${ }_{i t}$ takes the value of 1 if the firm issues debt and 0 if the firms issues equity. We define a firm as issuing debt if the ratio of net debt issued to total assets exceeds $5 \%$. Thus a firmis defined as issuing equity if the ratio of net equity exceeds $5 \% .{ }^{3}$ The key explanatory variable is the IVMV measure. Control variables are based on the literature. ${ }^{4}$

\section{Empirical Results}

In this section we report our empirical findings and discuss the implications. The aim of the paper is to look at how equity mispricing influences firms' security choice. We use a multivariate framework using a binary logistic model to test how well the equity mispricing ratio predicts the likelihood that a firm will issue a particular type of security. In our study the key explanatory variable will be the mispricing measure and our estimates also include known determinants as a control. Given the predictions of the market timing theory of capital structure, we expect the IVMV variable to have a positive coefficient in the debt vs. equity choice.

\subsection{Determinants Of Issue Choice And Issue Size}

Drawing from the literature we include known determinants as control variables. Firm size and asset tangibility are expected to have a positive coefficient as larger firms and firms with more tangible assets are more likely to issue debt over equity. The non-debt tax shield is expected to have a negative coefficient as DeAngelo and Masulis [22] argue that tax deductions can substitute as tax benefits of debt financing. We further expect the sign of the effective tax rate to be positive. We include leverage and industry leverage as per Elliott et al. [12] as a proxy for target leverage. Furthermore, we expect the coefficient of capital expenditure to be positive given that tangible investments are associated with a fixed stream of income and thus more likely to be financed via debt issues. Research and development on the other hand is expected to be negatively correlated to debt issues.

We report the regression results the model as expressed in equation (3) in the first column of Table 2 for pure debt issues versus pure equity issues. Our analysis control for firm fixed effects which allows us to control for time invariant firm factors; which could lead to spurious correlations between issue type and equity mispricing as well as to control for firm specific differences in our dataset which are time invariant such as economic shocks, talented management and specific customer characteristics. Our results reveal that the explanatory variables have some expected and some surprising results. Research and development expenses and non-debt tax shields have a negative sign as expected. Contrary to expectations, we find that the coefficients for asset tangibility and effective tax rate are negative. ${ }^{5}$ Importantly, the mispricing variable has a positive

\footnotetext{
${ }^{2}$ All our regressions control for firm fixed effects, report the coefficients and standard deviation which are clustered by firm and year in order to avoid correlation of observations across time for a given firm and correlation across firms for a given year [16]. This is to avoid biased standard errors in our unbalanced panel dataset regressions. Our results are robust to using White [17] standard errors although White standard errors are generally smaller and would yield 'more' significant results i.e. smaller $\mathrm{p}$-values.

${ }^{3}$ This approach is in line with similar studies in the literature [18], [19] and [20]. We exclude firms that issue both equity and debt.

${ }^{4}$ Our controls are based on our empirical priors [2], [8], [4] [12] and [21].

${ }^{5}$ Antoniou, Guney and Paudyal [22] document a similar correlation for effective tax rate.
} 
coefficient and is significant at $1 \%{ }^{6}$ Thus, equity mispricing strongly predicts security choice which confirms the predictions of the market timing theory.

\begin{tabular}{|c|c|c|}
\hline & Issue Choice & Issue Size \\
\hline \multirow[t]{2}{*}{ Constant } & $-1.1924 * * *$ & 0.8422 \\
\hline & $(0.4023)$ & $(0.9167)$ \\
\hline \multirow[t]{2}{*}{ Ln IVMV } & $1.4822 * * *$ & $1.6231 * * *$ \\
\hline & $(0.1024)$ & $(0.1922)$ \\
\hline \multirow[t]{2}{*}{ NDTS } & -1.2157 & -1.8122 \\
\hline & (2.1834) & $(2.8436)$ \\
\hline \multirow[t]{2}{*}{ TAN } & $-1.8420 * * *$ & $-2.420 * * *$ \\
\hline & $(0.4251)$ & $(0.5131)$ \\
\hline \multirow[t]{2}{*}{ SIZE } & 0.0465 & -0.0816 \\
\hline & $(0.0528)$ & $(0.0741)$ \\
\hline \multirow[t]{2}{*}{ TR } & -0.0174 & -0.0144 \\
\hline & $(0.0342)$ & $(0.0516)$ \\
\hline \multirow[t]{2}{*}{ LEV } & $7.5622 * * *$ & $7.8644 * * *$ \\
\hline & $(0.2455)$ & $(0.8455)$ \\
\hline \multirow[t]{2}{*}{ IND LEV } & -1.4230 & -1.8433 \\
\hline & $(3.2566)$ & $(4.4422)$ \\
\hline \multirow[t]{2}{*}{ ISSUE SIZE } & - & $-10.2277 * * *$ \\
\hline & - & $(1.0231)$ \\
\hline \multirow[t]{2}{*}{ CEX } & $8.044 * * *$ & $9.2246 * * *$ \\
\hline & (1.0237) & (1.6455) \\
\hline \multirow[t]{2}{*}{ RDE } & -2.8794 & -3.0224 \\
\hline & (2.5477) & (3.5164) \\
\hline \multirow[t]{2}{*}{ RDED } & 0.0466 & $0.6044 * *$ \\
\hline & $(0.2312)$ & $(0.2724)$ \\
\hline Observations & 2432 & 1422 \\
\hline $\mathrm{Chi}^{2}$ Test (p-values) & 0.0000 & 0.0000 \\
\hline Pseudo $\mathrm{R}^{2}$ & 0.3644 & 0.4022 \\
\hline Period & $1992-2011$ & $1992-2011$ \\
\hline Dependent $=1$ & 1312 & 802 \\
\hline Dependent $=0$ & 1120 & 620 \\
\hline
\end{tabular}

Hovakimian et al. [2] argue that issue size should be considered differently from issue choice. Based on their findings, we consider issue size separately. Drawing from their study, we define issue size as net debt issued scaled by assets at the beginning of the year. The results are reported in the second column of Table 2. Similar to Hovakimian et al. [19] we include issue size as a control variable and expect a negative correlation due to debt issues generally being smaller than equity issues. We find that the IVMV variable to be positive as expected and significant at $1 \%$. Furthermore, we find that the effect is larger for issue size, where the probability for firms issuing larger issues to reflect equity mispricing is higher as firms are more likely to time issues and hence make a larger debt issue during periods of undervaluation, and conversely a larger equity issue during periods of overvaluation. This allows us to conclude that the impact of market timing is larger on issue size relative to issue choice.

\subsection{Non-Linear Behavior In Issue Choice}

We further split our sample into firm-years which are undervalued where IVMV is greater than 1 and report the results in the first three columns of Table 3 while firm-years which are overvalued where IVMV is less than 1 are reported in the last three columns of Table 3 . The regression in the last three columns of Table 3 switches the definition of the binary dependent variable for the issue type where if firms issue equity variable takes the value of 1 and 0 if firms are issuing debt in order to capture the positive coefficient of the IVMV

${ }^{6} \mathrm{We} \log$ all the mispricing measure as the data is highly skewed. 
explanatory variable. The first column in Table 3 shows that the coefficient for the mispricing measure remains positive and significant at $1 \%$ as expected.

In the second and third column we expand the model by adding in the quadratic and cubic term for the mispricing measure in order to test for non-linearity in issuing type choice. The second column shows that the first order term is insignificant and the second order term is significant at $1 \%$ and positive. Our results indicate that firms do not prefer to time the equity market by issuing debt relative to equity when equities are slightly undervalued and only have a preference for debt issues when the extent of undervaluation of equities are larger. One possible explanation for this behavior would be that managers are reluctant to allow more scrutiny into their actions which would be brought about by debt issues and show concern about the disciplining element of debt issues via interest payments (i.e. information asymmetry and agency theory implications). Another plausible explanation would be that managers are trading off the benefit that may be gained from relying on a relatively cheaper source of financing in order to protect future growth prospects as an increase in leverage levels may limit firms' future financial flexibility. The last possible explanation would be managers are more concerned with the extent of mispricing and working to protect shareholders' interests. Thus they would be keen on issuing debt as signal to the market that equities are severely undervalued. It could be that lesser levels of undervaluation would not prompt such actions from managers are they would no doubt come at a cost and managers may be weighing the potential benefit versus the potential costs. We find a similar pattern in the third column as the third order term in added into our model. It has a positive coefficient and is statistically significant at $1 \%$.

The results in the fourthcolumn of Table 3 shows that the mispricing is also positive and significant as expected. Results in the fifth column shows that the first order term is significant while the quadratic term is insignificant. This indicates that managers only prefer to time equity issues during slight levels of overvaluation and do not time equity issues during periods of severe overvaluation. One plausible explanation would be that managers do not see severely inflated prices being maintained in the longer terms in order for them to be able to time the market. Another possible explanation for this would be that managers are alert about extent of mispricing and would be keen on detecting irrational overvaluation by investors and thus would be inclined to issue equities sooner rather than later when prices are increasing. In a scenario of a price rally and prices keep increasing over a sustained period of time, investors may interpret an announcement to issue equity as a signal of overvaluation from managers and thus managers would be keen to avoid this by issuing sooner rather than later. The introduction of the cubic term in the third column further confirms our results as the coefficient remains positive and significant for the first order term while second order term and third order term is insignificant.

\begin{tabular}{|l|rrr|rrr|}
\hline \multicolumn{7}{|c|}{ Table 3: Non-linear Behavior in Issue Choice } \\
\hline \multirow{4}{*}{ Constant } & \multicolumn{7}{|c|}{ Undervalued Firms (IVMV > 1) } & \multicolumn{2}{c|}{ Overvalued Firms (IVMV < 1) } \\
\cline { 2 - 7 } Ln IVMV & $-2.4422^{* * *}$ & $-1.9455^{* * *}$ & $-1.8471^{* * *}$ & 0.9121 & 0.8744 & 0.8741 \\
& $(0.6031)$ & $(0.5217)$ & $(0.5018)$ & $(1.9455)$ & $(1.9021)$ & $(1.9002)$ \\
Ln IVMV & $1.9422 * * *$ & 0.2422 & 0.1936 & $1.2122 * * *$ & $1.1923 * * *$ & $1.1724 * * *$ \\
& $(0.3121)$ & $(0.1977)$ & $(0.2037)$ & $(0.1088)$ & $(0.0987)$ & $(0.0954)$ \\
Ln IVMV & - & $1.7866 * * *$ & 0.8177 & - & 0.0356 & 0.0317 \\
& - & $(0.2548)$ & $(0.6954)$ & - & $(0.2897)$ & $(0.2788)$ \\
NDTS & - & - & $1.5281 * * *$ & - & - & 0.0066 \\
& - & - & $(0.2067)$ & & - & $(0.0108)$ \\
TAN & -2.1130 & -2.0018 & -1.9474 & -0.8455 & -0.8267 & -0.8217 \\
SIZE & $(1.9146)$ & $(1.8471)$ & $(1.8021)$ & $(2.3477)$ & $(2.4188)$ & $(2.4186)$ \\
& $-2.0131^{* * *}$ & $-2.0102 * * *$ & $-2.0074 * * *$ & 1.2456 & 1.2561 & 1.2570 \\
TR & $(0.4988)$ & $(0.4925)$ & $(0.4013)$ & $(1.0645)$ & $(1.0714)$ & $(1.0716)$ \\
& 0.0615 & 0.0618 & 0.0626 & 0.0120 & 0.0119 & 0.0118 \\
LEV & $(0.0561)$ & $(0.0560)$ & $(0.0531)$ & $(0.0209)$ & $(0.0208)$ & $(0.0207)$ \\
& -0.2019 & -0.2118 & -0.2120 & -0.0087 & -0.0085 & -0.0085 \\
IND LEV & $(0.2084)$ & $(0.2011)$ & $(0.2164)$ & $(0.5016)$ & $(0.5023)$ & $(0.5024)$ \\
& $5.9443 * * *$ & $5.9366 * * *$ & $5.9321 * * *$ & $8.4499 * * *$ & $8.4510 * * *$ & $8.4519 * * *$ \\
CEX & $(0.9844)$ & $(0.9877)$ & $(0.9891)$ & $(0.6156)$ & $(0.6168)$ & $(0.6170)$ \\
& -1.8426 & -1.8832 & -1.8856 & -0.9122 & -0.9119 & -0.9118 \\
& $(2.7428)$ & $(2.6898)$ & $(2.6954)$ & $(4.0261)$ & $(4.0260)$ & $(4.0260)$ \\
& $10.2263 * * *$ & $10.2361 * * *$ & $10.2401 * * *$ & 2.1123 & 2.0120 & 2.0118
\end{tabular}


Non-linearity in timing the equity market and debt-equity choice of UK firms.

\begin{tabular}{|l|rrr|rrr|} 
& $(1.2457)$ & $(1.2512)$ & $(1.2537)$ & $(1.8722)$ & $(1.8820)$ & $(1.8821)$ \\
RDE & -3.2654 & -3.2587 & -3.2540 & 0.1237 & 0.1241 & 0.1242 \\
RDED & $(2.9455)$ & $(2.9178)$ & $(2.9174)$ & $(1.0844)$ & $(1.0849)$ & $(1.0850)$ \\
& 0.0167 & 0.0213 & 0.0218 & -0.0804 & -0.0808 & -0.0808 \\
& $(0.1947)$ & $(0.1988)$ & $(0.1991)$ & $(0.7149)$ & $(0.7151)$ & $(0.7150)$ \\
\hline Observations & 1169 & 1169 & 1169 & 1263 & 1263 & 1263 \\
Chi $^{2}$ Test (p-values) & 0.0000 & 0.0000 & 0.0000 & 0.0000 & 0.0000 & 0.0000 \\
Pseudo R & 0.4344 & 0.4127 & 0.4088 & 0.3120 & 0.3084 & 0.2949 \\
Period & $1992-2011$ & $1992-2011$ & $1992-2011$ & $1992-2011$ & $1992-2011$ & $1992-2011$ \\
Dependent $=1$ & 945 & 945 & 945 & 896 & 896 & 896 \\
Dependent $=0$ & 224 & 224 & 224 & 367 & 367 & 367 \\
\hline
\end{tabular}

Note: Figures report coefficients while standard errors are reported in parentheses. The first three columns report the results for observations where firms' equities are undervalued whilst the last three columns firm-years where equities are overvalued. $* * * * *$ and $*$ indicates significance at $1 \%, 5 \%$ and $10 \%$ respectively

\section{Conclusion}

Our paper empirically tests the equity market timing theory of capital structure using unbalanced UK panel data. The initial results confirm the predictions of the theory and show that equity mispricing influences issuing choice. The effect is statistically and economically significant as firms are more likely to issue debt (equity) in periods of undervaluation (overvaluation). Building on our initial analysis as well as the work suggested by the literature, we further test for non-linearity in timing behavior and how it influences security issue choice. We find that managers do exhibit non-linear behavior in timing the equity market. Based on our findings we conclude that managers are only more likely to favour debt over equity during periods of undervaluation if the extent of mispricing is severe. The results suggest that this could be as a result of the interaction between firms' level of information asymmetry, agency considerations as well as managerial intent on preserving financial slack (flexibility). Contrarily, manager only favour equity due to overvaluation during lower levels of mispricing rather than higher levels of deviation from intrinsic values. Thus, managers are seen to be keenly aware of windows of opportunity to time the market to lower overall cost of capital and deliver value to shareholders. The evidence points towards a dynamic and complex relation between the signaling effect and timing of equity issues. Our result raise some interesting questions that remain unanswered and warrants further research to examine on how the extent of mispricing interplays with several other forces that influence issue choice (e.g. the dynamic interaction between agency implications and information asymmetry with timing the market).

\section{Acknowledgements}

We are indebted to Muhammed-Shahid Ebrahim, Abdullah Iqbal, Gulnur Muradoglu, and Richard Warr for their valuable feedback, comments and suggestions. We also thank the seminar participants at the University of Hull, UK and Cass Business School, City University of London.

\section{References}

[1] M. Baker, and J. Wurgler, Market timing and capital structure. Journal of Finance 57, 2002, 1-32.

[2] A. Hovakimian, T. Opler, and S. Titman, The debt-equity choice. Journal of Financial and Quantitative Analysis 36, 2001, 1-24.

[3] A. Hovakimian, Are observed capital structures determined by equity market timing? Journal of Financial and Quantitative Analysis 41, 2006, 221-243.

[4] A. Mahajan and S. Tartaroglu, Equity market timing and capital structure: International evidence. Journal of Banking and Finance $32,2008,754-766$

[5] J. Graham and C. Harvey, The theory and practice of corporate finance: evidence from the field, Journal of Financial Economics $60,2001,187-243$

[6] D. Brounen, A. de Jong, and K. Koedijk, Capital structure policies in Europe: Survey evidence. Journal of Banking and Finance 30, 2006, 1409-1442.

[7] P. Marsh, The choice between debt and equity: An empirical study. Journal of Finance 37, 1982, 121-144.

[8] M. Flannery, M. and K. Rangan, Partial adjustment toward target capital structures, Journal of Financial Economics 79, 2006, 469506.

[9] S. Byoun, How and when do firms adjust their capital structure towards targets? Journal of Finance 63, 2008, 3069 - 3096

[10] R. Warr, W. Elliott, J. Koeter-Kant O. Oztekin, Equity mispricing and leverage adjustment costs. Journal of Financial and Ouantitative Analysis 47, 2012, 589 - 616.

[11] W. Elliott, J.Koeter-Kant and R. Warr, A valuation-based test of market timing. Journal of Corporate Finance 13, 2007, 112-128.

[12] W. Elliott, J.Koeter-Kant and R. Warr, Market timing and the debt-equity choice, Journal of Financial Intermediation 17, 2008, 175-197.

[13] R. D'Mello and P. Shroff, Equity undervaluation and decisions related to repurchase tender offers: An empirical investigation. Journal of Finance 55, 2000, 2399 - 2425.

[14] M. Rhodes-Kropf, D. Robinson and S. Viswanathan, Valuation waves and merger activity: The empirical evidence, Journal of Financial Economics 77, 2005, 561 - 603 
[15] E. Fama and K. French, Industry costs of equity, Journal of Financial Economics 43, 1997, 153 - 193.

[16] M. Petersen, Estimating standards errors in finance panel data sets: Comparing approaches. Review of Financial Studies 22, 2009, $435-480$

[17] H. White, Heteroskedastic-consistent covariance matrix estimator and a direct test of heteroskedasticity, Econometrica 48, 1980, $817-838$.

[18] A. Hovakimian, The role of target Leverage in security issues and repurchases, Journal of Business 77, $2004,1041-1071$.

[19] A. Hovakimian, G. Hovakimian and H. Tehranian, Determinants of target capital structure: the case of dual debt and equity issues. Journal of Financial Economics 71, 2004, 517-540.

[20] P. Gaud, M. Hoesli, and A. Bender, Debt-equity choice in Europe, International Review of Financial Analysis 16, 2001, 201-222

[21] R. Rajan, R. and L. Zingales, L. What do we know about capital structure? Some evidence from international data Journal of Finance 50, 1995, $1421-1460$.

[22] H. DeAngelo and R. Masulis, Optimal capital structure under corporate and personal taxation, Journal of Financial Economics 8, $1980,3-29$.

[23] A. Antoniou, Y. Guney, and K. Paudyal. The determinants of capital structure: Capital market-oriented versus bank-oriented institutions. Journal of Financial and Quantitative Analysis 43, 2008, 59-92. 